\title{
Enseñando y aprendiendo el espacio geográfico por medio del tacto: orientaciones metodológicas
}

Coll Escanilla, Alejandra; Barrientos Guzmán, Teresa y Huentelemu Ramírez, Víctor. Ediciones Universidad Tecnológica Metropolitana, Santiago de Chile, 2017, 173 pp. ISBN: 978-956-9677-11-3

\section{Regina Araujo de Almeida Universidade de São Paulo}

El trabajo en cuestión presenta la producción y el uso de mapas táctiles, centrándose principalmente en la enseñanza y el aprendizaje del espacio geográfico a través del tacto. Además de la propuesta teórica y las pautas metodológicas, explica las técnicas para la construcción de imágenes gráficas y cartográficas en relieve. La aplicación práctica resultante de muchos años de investigación en el campo de la cartografía táctil ha traído al texto una base científica en profundidad y, al mismo tiempo, consiste en contenido que es muy accesible para maestros y padres de niños y jóvenes con discapacidad visual. Sin duda, ayudará en la enseñanza de la geografía, mostrando caminos para la percepción, el conocimiento y la representación gráfica del espacio en el que vivimos. El acceso a la información espacial, por parte de personas ciegas o con baja visión es complejo y requiere atención especial, al igual que la introducción a conceptos geográficos y cartográficos. Este libro presenta estrategias didácticas que permiten la construcción y el uso de mapas táctiles en la escuela y la vida cotidiana, facilitando la verdadera inclusión de personas con discapacidad visual en el mundo de las imágenes.

El contenido del libro está dividido en cuatro capítulos, además de la Introducción y la Bibliografía. Al final hay un Anexo con mapas táctiles adaptados que son excelentes ejemplos de las orientaciones metodológicas y técnicas presentadas a lo largo del texto.

El Capítulo 1, presenta metodologías de enseñanza-aprendizaje con énfasis en el mapa táctil y los estudiantes con discapacidad visual, destaca los requisitos para usar el lenguaje gráfico táctil, como la experiencia con la percepción táctil, las habilidades de orientación y movilidad, y conocimiento de dibujos táctiles.

El Capítulo 2, analiza el uso y la gestión de los mapas táctiles, destacando la importancia de la capacitación para la elaboración y el uso de mapas por personas con discapacidad visual. Discute el cuidado necesario para su construcción, 
considerando el uso del Braille y los diferentes materiales disponibles para la adaptación. Se analiza la simbología táctil y se muestran varias imágenes con mapas, símbolos táctiles y leyendas, y se exploran las diferencias entre la percepción visual y táctil de los mapas.

El Capítulo 3, presenta las estrategias de enseñanza para los mapas táctiles, con la metodología y las técnicas de exploración de mapas. Es la parte más extensa del libro, con pasos detallados para usar el mapa, que cubre la planificación, los objetivos y la evaluación inicial del estudiante. Las técnicas para explorar el mapa táctil se analizan con varios ejemplos.

El Capítulo 4, titulado "Elementos básicos que debería tener un mapa táctil", trata el análisis de elementos de mapa adaptados y resume las recomendaciones para trabajar con estos mapas. Se destacan las cuestiones relacionadas con la simbología táctil, con especial atención al lenguaje Braille y la importancia de las texturas que reemplazan los colores. En este capítulo se presentan y discuten ejemplos de técnicas y materiales utilizados en la cartografía táctil, así como numerosos mapas táctiles.

Al final de los capítulos, aparece una bibliografía basada en la experiencia de los autores y que será probablemente una base para futuras publicaciones sobre el tema, seguida de un anexo con mapas táctiles adaptados: Mapa físico de Brasil, Mapa político de América del Sur y Mapa del mundo. Para cerrar están los créditos, los datos académicos del Prólogo y las Presentaciones, así como la biografía de los autores.

El libro, publicado en dos idiomas (español e inglés), además del contenido altamente relevante, llama la atención por su cuidado con la forma; es una impresión realmente excepcional en todos los aspectos. De especial interés es el anexo con los mapas táctiles adaptados, que finaliza esta magnífica publicación. Se sugiere, teniendo en consideración los aportes relevantes de esta publicación, que sería recomendable producir una versión editorial más económica, para facilitar una gran circulación con la posibilidad de enviar a las escuelas en todos los países de América Latina, y llegar así a miles de maestros y padres, mejorando la educación de un número mucho mayor de estudiantes con discapacidad visual.

La mayoría de los profesionales que trabajan con niños y jóvenes con diversos grados de discapacidad visual, no dominan la teoría ni la práctica de dibujar representaciones gráficas y cartográficas, lo que requiere mucha capacitación para trabajar con la producción y el uso del mapa táctil. Este libro aborda estas brechas al presentar estrategias y procedimientos de enseñanza para maestros y padres, trayendo conceptos espaciales y conocimientos geográficos que son accesibles para esta audiencia.

Los notables resultados de este libro fueron logrados por un equipo multidisciplinario de investigadores altamente calificados, coordinado por la profesora titular Alejandra Coll Escanilla, fundadora y directora del Centro de 
Cartografía Táctil (CECAT) de la Universidad Tecnológica Metropolitana de Chile (UTEM). Este programa ha expandido su experiencia en el campo de la cartografía táctil en los últimos 20 años, con el importante apoyo del Instituto Panamericano de Geografía e Historia (IPGH/OEA).

Es destacable el trabajo sistemático realizado por el equipo de investigadores, profesionales y técnicos del CECAT desde el año 1994, quienes hasta la fecha han desarrollado ocho proyectos de investigación de largo aliento, todos de carácter interdisciplinario e internacional (Argentina, Brasil, Chile y Perú). Los proyectos han otorgado recursos para profundizar en el conocimiento, la producción y la difusión de las experiencias adquiridas a través de más de quince cursos de capacitación internacionales, donde han sido perfeccionados más de quinientos profesores y profesionales vinculados al área de la educación y de las ciencias de la tierra.

El resultado de la investigación aplicada derivó en el desarrollo de más de seiscientos productos relacionados como mapas táctiles y material didáctico multisensorial para la enseñanza de la geografía y otras disciplinas asociadas. Todos los productos elaborados antes de ser distribuidos, son evaluados por personas que presentan discapacidad visual, siendo beneficiados posteriormente 21 países de América Latina.

El éxito de estos proyectos, con una coordinación efectiva y tantos resultados positivos acumulados a lo largo del tiempo, explican la calidad del trabajo y, por lo tanto, la relevancia de esta publicación. Considero este libro un excelente trabajo académico y científico, tanto en la forma como en el contenido. En resumen, recomiendo altamente su lectura, porque sin duda marcará una gran diferencia en la enseñanza de la geografía y la cartografía a estudiantes con discapacidad visual, contribuyendo a la formación de sus profesores y a la inclusión de los estudiantes. 